\title{
Lonchocarpus cultratus (Vell.) A.V.G. Azevedo \& H.C. Lima (Fabaceae) growth under different shade and water availability conditions ${ }^{1}$
}

\author{
Caroline Barbeiro ${ }^{2}$, Mariza Barion Romagnolo ${ }^{2}$, Lindamir Hernandez Pastorini ${ }^{2}{ }^{*}$
}

10.1590/0034-737X201865060004

\begin{abstract}
Light and water availability are among the environmental factors that most influence plant growth and development. The ability to acclimate to shade and tolerate drought can be assessed by growth characteristics. Thus, the objective of this study was to analyze the effect of water availability and shading on the initial growth of Lonchocarpus cultratus, a tree species, common name 'embira-de-sapo', abundant in several areas of South and Southeastern Brazil. The experiment was arranged in a $3 \times 2$ factorial completely randomized design. The plants were kept under $0 \%, 50 \%$, and $80 \%$ shading and two conditions of water availability (daily irrigation - ID and twice a week - NDI). The variables height, root length, dry biomass of leaves, stem, and root were evaluated at 30, 60 and 90 days after emergence (DAE). Total, a, and b chlorophyll, mycorrhizal colonization and, nodulation were determined. Death of young plants maintained at $0 \%$ NDI occurred at the beginning of growth. At 90 DAE, plants kept under $80 \%$ shading and ID showed the highest height and etiolated plants due to the reduction of light intensity in this treatment. Over the experimental period, $0 \%$ and 50\% shaded plants irrigated daily had the highest percentage of mycorrhizal colonization, and nodulation was observed in all plants regardless of the treatment.
\end{abstract}

Keywords: leaf area; chlorophyll; mycorrhizal colonization; dry biomass; nodulation.

\section{RESUMO}

\section{Crescimento de Lonchocarpus cultratus (Vell.) A.V.G. Azevedo \& H.C. Lima (Fabaceae) mantidos em diferentes condições de sombreamento e disponibilidade hídrica}

Dentre os fatores ambientais, a luz e a disponibilidade hídrica são alguns dos que mais influenciam o crescimento e desenvolvimento das plantas. A capacidade de aclimatação ao sombreamento e tolerância a períodos secos pode ser verificada por meio de características de crescimento. Assim, o objetivo deste trabalho foi analisar o efeito da disponibilidade hídrica e sombreamento sobre o crescimento inicial de Lonchocarpus cultratus, espécie arbórea, conhecido como embira-de-sapo, heliófita e abundante em diversas áreas do Sul e Sudeste do Brasil. O delineamento experimental foi inteiramente casualizado, em esquema fatorial 3x2, no qual as plantas foram mantidas em $0 \%, 50 \%$ e $80 \%$ de sombreamento e sob duas condições de disponibilidade hídrica (irrigação diária - ID e duas vezes por semana - NID). Foram avaliados aos 30, 60 e 90 dias após a emergência (DAE), as variáveis altura, comprimento da raiz, biomassa seca das folhas, do caule e da raiz e quantificou-se o teor de clorofila $a, b$ e total, além da colonização micorrízica e nodulação. Observou-se a morte de plantas jovens mantidas a 0\% NID, logo no início de seu crescimento. Aos 90 DAE observouse maior altura das plantas mantidas sob $80 \%$ ID, evidenciando estiolamento das plantas devido à redução da intensidade luminosa neste tratamento. Nesse período as plantas a $0 \%$ e sob $50 \%$ de sombreamento e irrigadas diariamente apresentaram maior porcentagem de micorrização, observando-se também a nodulação em todas as plantas, independentemente-do tratamento.

Palavras-chave: área foliar; clorofila; colonização micorrízica; biomassa seca; nodulação.

\footnotetext{
Submitted on March 23 $3^{\text {rd }}, 2018$ and accepted on September 18 th, 2018

${ }^{1}$ Research financed by CNPq.

${ }^{2}$ Universidade Estadual de Maringá, Programa de Pós-Graduação em Biologia Comparada, Maringá, Paraná, Brazil. caroline-lila@hotmail.com; mbromagnolo@gmail.com; lhpastorini@uem.br

*Corresponding author: lhpastorini@uem.br
} 


\section{INTRODUCTION}

Lonchocarpus cultratus (Vell.) A.M.G. Azevedo \& HC Lima (Fabaceae) is one of the most abundant species in several areas of southern and southeastern Brazil, usually growing in gallery or riparian forests associated with seasonally dry and humid tropical forests (Silva \& Tozzi, 2012). The species plays a fundamental role in the natural regeneration of devastated forest areas, including riparian areas, since it is able to grow in poor and dry soil conditions (Panarari et al., 2004).

Studies on the initial plant development provide useful data for work in nurseries, seed storage, and forest regeneration (Souza \& Oliveira, 2004), helping in the recovery of degraded areas. In tropical rainforests, the availability of light and water are the most important factors for the growth and survival of young plants (Amissah $e t$ al., 2015).

At the beginning of development, seedlings have a small root system and the soil exploration capacity to acquire water and mineral nutrients interferes with the competitiveness of individuals, favoring or hindering plant recruitment. The beneficial interactions between plants and microorganisms in the soil favor plant establishment. The mycorrhizal association is one of the most common symbioses in the forest ecosystem (Smith \& Read, 2008), contributing to supply nutrients to plants, mainly phosphorus. The mycorrhizal association also gives the plant greater tolerance to environmental stresses, both biotic and abiotic, as well as a greater tolerance to water deficit (Beltrano \& Ronco, 2008).

Tree species vary in their ability to respond to changes in light availability. According to Silva et al. (2007) and Caron et al. (2010), the efficiency in plant growth is related to the ability of a seedling to adapt to different light levels in the environment. Besides light, water availability is one of the main factors affecting plant growth and development. Water deficit causes turgor loss, stomatal closure, and reduced cell expansion, resulting in low plant metabolic activity (Mendes et al., 2013). Thus, physiological and phenological responses of trees to varied environmental conditions allow predicting how forests will respond to future climate changes (Brzostek et al., 2014).

Among the analyzed characteristics, shoot and root biomasses are important variables in the evaluation of plant development and capacity of acclimatization to different shading regimes and tolerance to drought. In addition, chlorophyll quantification can indicate the plant physiological status and estimate its productivity (Ferri, 2004).

Considering the importance of studies on the establishment of native plants and their responses to environmental adversities, this study aimed to evaluate

Rev. Ceres, Viçosa, v. 65, n.6, p. 491-499, nov/dez, 2018 the influence of water and light availability on the growth of L. cultratus young plants.

\section{MATERIAL AND METHODS}

\section{Plant material and experiment design}

Mature fruits of L. cultratus were collected from five trees in the Caiuá Ecological Station, a remnant of the Semideciduous State Forest in the Mata Atlântica Biome, in the municipality of Diamante do Norte, PR. The fruits were taken to the Plant Physiology laboratory, and seeds were removed by hand.

The seeds were placed in 12 x $18 \mathrm{~cm}$ black plastic bags; containing sieved, organic matter-free soil and added with simple superphosphate (300 mg. $\mathrm{dm}^{-3}$ soil).

The experiment was arranged in a $3 \times 2$ factorial completely randomized design, with three leght levels $(0 \%$, $50 \%$ and $80 \%$ shade) and two levels of water availability [plants irrigated every day (ID); and plants irrigated twice a week (NDI)]. Thus, the experiment had six treatments: $0 \%$ shade and irrigated twice a week ( $0 \%$ NDI); $50 \%$ shade and irrigated daily (50\% ID); 50\% shade and irrigated twice a week (50\% NDI); $80 \%$ shade and irrigated daily $(80 \%$ ID); and $80 \%$ shade and irrigated twice a week ( $80 \%$ NDI).

Three evaluations were carried out during the development of the plants at 30,60 and 90 days after emergence (DAE), using 49 plants at 30 DAE, 53 plants at $60 \mathrm{DAE}$, and 50 plants at $90 \mathrm{DAE}$, totaling 152 plants.

The plants were irrigated with tap water. In the NDI treatment, plants were kept with $45 \%$ of the ID treatment water content.

The experiment was conducted in greenhouse, from November 2013 to February 2014.

\section{Growth assessment}

The following characteristics were analyzed: height (H), root length (RL), dry biomass of leaf (DLB), stem (DSB), and root (DRB) and leaf area (LA). However, it was not possible to obtain the dry biomass of leaves, stem, and root for plants maintained in the $0 \%$ NDI treatment, at $30 \mathrm{DAE}$, due to the reduced number of plants. Three plants of this treatment were used to obtain $\mathrm{H}$ and $\mathrm{RL}$ and the remaining plants $(n=3)$ were used for the physiological evaluations. Three plants were also used for the evaluation of the $50 \%$ ID treatment at 30 DAE. For all of the other treatments, five plants were used to analyze the growth characteristics.

Young plants, which still had reserve cotyledons, at 30 DAE, had the dry biomass also obtained for these structures.

For dry biomass determination, the plant material was oven dried at $60^{\circ} \mathrm{C}$ for 72 hours and the mass weighed on an analytical balance.

The height and length of the main root were determined using a millimeter ruler. 
For the analysis of the leaf area, fully expanded leaves of each plant were digitized in a scanner. Leaf areas were determined using the image analysis software Image-Pro® Plus 4.5 (Media Cybernetics, Rockville, MD, USA).

\section{Quantification of photosynthetic pigments}

Quantification of chlorophyll $a, b$, and total was performed using plant material collected at 30,60 and 90 days after emergence, in different plants from those used for the evaluation of growth characteristics. For the analysis of leaf pigments, the plants were collected at the same time in the morning. The leaves were weighed, crushed, and then macerated with $80 \%$ acetone. The solution obtained was filtered and chlorophyll was quantified using a spectrophotometer at $645 \mathrm{~nm}$ and 663 nm according to Arnon (1949).

\section{Evaluation of arbuscular mycorrhizal colonization and rhizobium nodules in roots}

The roots used in this evaluation came from the plants used to evaluate the chlorophyll content. Three plants at 30 and 60 DAE were used for the $0 \%$ NDI treatment, and the same number of plants were used for the $50 \%$ ID treatment at $30 \mathrm{DAE}$. The other treatments were analyzed with five plants at 30,60, and 90 DAE.

Clearing and staining of roots were performed at each collection. The roots were washed in tap water and taken to the water bath in tubes filled with $10 \% \mathrm{KOH}$ for clearing of the cortex. The roots were rinsed again with tap water and acidified with $5 \% \mathrm{HCl}$. Then, in a water bath, they were stained with trypan blue (Phillips \& Hayman, 1970). The evaluation of the root colonization was carried out using a stereoscope microscope, according to the gridline intersect method described by Giovannetti \& Mosse (1980).

The percentage of arbuscular mycorrhizal colonization (AMC) was determined using a stereoscopic microscope, based on the presence or absence of characteristic intraradicular structures such as vesicles, hyphae, and arbuscules, using the gridline intersect method (Giovannetti \& Mosse, 1980).

The presence of nodules resulting from the association of $L$. cultratus roots with nitrogen fixing bacteria was visually observed at each time of collection and treatment.

\section{Data analysis}

The data of the growth characteristics (H, RL, DLB, DSB, DRB, LA), chlorophyll content, and percentage of mycorrhizal colonization were subjected to analysis of variance, and the means were compared by the Tukey test at $5 \%$ probability.

\section{RESULTS AND DISCUSSION}

\section{Growth assessment}

At 30 DAE, the primary growth of L. cultratus was not influenced by light intensity and water availability, as observed for height $(\mathrm{H})$ and root length (RL), thus, plant average height was $9.79 \mathrm{~cm}$, and root mean length was $14.46 \mathrm{~cm}$. However, lower DLB was observed for the plants kept under 50\% NDI and lower DSB and DRB for shaded plants, when compared with the plants of the $0 \%$ ID treatment (Table 1).

A significant number of plants died in the treatment with $0 \% \mathrm{NDI}$, indicating that $L$. cultratus showed no acclimatization to the highest light intensity combined with the lower water availability, even in the initial stages of growth. Amo-Rodrigues \& Gomez-Pompa (1979) reported that the initial developmental period of a plant is considered critical in the life cycle of many plant species. Thus, seedlings are more susceptible to dry periods than plants in later stages of development (Ferreira et al., 2012).

Factors such as high irradiance and low water or nutritional availability make it difficult to succeed in plant establishment in the juvenile phase (Gonçalves et al., 2009), which was observed in the present study for the treatment $0 \%$ DI.

At $60 \mathrm{DAE}$, there was no interaction of light factors and water availability in relation to root length (RL) and dry root biomass (DRB), and the plants kept in the different treatments had average RL of $15.58 \mathrm{~cm}$ and DRB of $0.043 \mathrm{~g}$. Plants from the treatments $50 \% \mathrm{NDI}$ and $80 \%$ ID had higher height than the plants under $0 \%$ shade (Table 1). Plants under 50\% ID had higher DLB and DSB than plants under $0 \%$ ID and $80 \%$ NDI.

At 90 DAE, all plants from the $0 \%$ NDI treatment had died, therefore, it was not possible to evaluate the growth characteristics in this treatment.

The plants kept in the different treatments were not significantly different for RL and DSB at 90 DAE, with mean of $16.0 \mathrm{~cm}$ for RL and $0.054 \mathrm{~g}$ for DSB. The highest height of the shoot was found in the plants under $80 \%$ ID, evidencing plant etiolation, due to the lower light intensity. Plants under 50\% NDI, 80\% ID and 80\% NDI had lower DRB than plants maintained under 0\% ID (Table 1 and Figure 2).

The light availability in forest environments influences plant growth (Amissah et al., 2015). Thus tree species vary in their ability to respond to changes in light availability. Ferreira et al. (2012) observed a tendency to increase the root mass of tree species of Mimosaceae submitted to high light intensities, which was found for plants in the treatment $0 \%$ ID of this study (Figure 2A).

Previous studies have shown allocation of less biomass to the root system in relation to the shoots as light availability decreases (Li et al., 2016), while water stress can limit leaf growth (Rawat et al., 2017).

-Rev. Ceres, Viçosa, v. 65, n.6, p. 491-499, nov/dez, 2018 
At 30 DAE, L. cultratus plants from the treatments $80 \%$ ID and $80 \%$ NDI showed greater LA than plants under the treatments $0 \%$ ID and 50\% NDI (Table 2).

At 60 DAE, there was no significant difference between the plants under shade and the lowest LA was found for plants from the $0 \%$ ID treatment. At 90 DAE, the LA was significantly different only between the plants from $0 \%$ ID and $80 \%$ ID (Table 2).

Plants under shade generally have higher LA as a way of increasing the light receiving area (Taiz \& Zeiger, 2009), which was observed at 60 DAE for plants kept under shade, regardless of water availability. Increase in LA with the increase in shading level in young plants was reported by Tang et al. (2015) for of Torreya grandis Fortune ex Lindl. and Rego \& Possamai (2006) for Cariniana legalis (Mart.) Kuntze (jequitibá-rosa).

Low irradiance leads to greater allocation of biomass to leaves in detriment of roots and promotes increase in leaf area, and this growth is one of the strategies to increase radiation use efficiency. This result was observed in young L. cultratus plants, when kept under shading,

Table 1: Shoot height (H), root length (RL), dry leaf biomass (DLB), dry stem biomass (DSB), and dry root biomass (DRB) of Lonchocarpus cultratus at 30, 60, and 90 days after emergence (DAE) kept in greenhouse under the treatments: $0 \%$ shade, 50\% shade; $80 \%$ shade; ID: daily irrigation; NDI: non-daily irrigation

\begin{tabular}{|c|c|c|c|c|c|c|c|c|c|c|c|}
\hline & & \multicolumn{2}{|c|}{$\mathbf{H}(\mathrm{cm})$} & \multicolumn{2}{|c|}{$\mathbf{R L}(\mathrm{cm})$} & \multicolumn{2}{|c|}{ DLB (g) } & \multicolumn{2}{|c|}{ DSB (g) } & \multicolumn{2}{|c|}{ DRB (g) } \\
\hline & & ID & NDI & ID & NDI & ID & NDI & ID & NDI & ID & NDI \\
\hline \multirow{3}{*}{$30 \mathrm{DAE}$} & $0 \%$ & $9.6 \mathrm{a}^{*}$ & $7.33 \mathrm{a}$ & $19.10 \mathrm{a}$ & $13.30 \mathrm{a}$ & $0.102 \mathrm{a}$ & - & $0.074 \mathrm{a}$ & - & $0.052 \mathrm{a}$ & - \\
\hline & $50 \%$ & $11.0 \mathrm{a}$ & $7.30 \mathrm{a}$ & $12.56 \mathrm{a}$ & $15.10 \mathrm{a}$ & $0.086 \mathrm{a}$ & $0.036 \mathrm{~b}$ & $0.056 \mathrm{ab}$ & $0.016 \mathrm{c}$ & $0.022 \mathrm{~b}$ & $0.017 \mathrm{~b}$ \\
\hline & $80 \%$ & $10.4 \mathrm{a}$ & $13.1 \mathrm{a}$ & $14.60 \mathrm{a}$ & $12.10 \mathrm{a}$ & $0.076 \mathrm{a}$ & $0.093 \mathrm{a}$ & $0.048 \mathrm{ab}$ & $0.053 \mathrm{ab}$ & $0.015 \mathrm{~b}$ & $0.019 \mathrm{~b}$ \\
\hline \multirow{3}{*}{$60 \mathrm{DAE}$} & $0 \%$ & $9.00 \mathrm{~b}$ & $6.86 \mathrm{c}$ & $15.7 \mathrm{a}$ & $13.46 \mathrm{a}$ & $0.110 \mathrm{~b}$ & - & $0.033 \mathrm{ab}$ & - & $0.058 \mathrm{a}$ & - \\
\hline & $50 \%$ & $12.74 \mathrm{ab}$ & $13.30 \mathrm{a}$ & $20.6 \mathrm{a}$ & $17.4 \mathrm{a}$ & $0.187 \mathrm{a}$ & $0.133 \mathrm{ab}$ & $0.053 \mathrm{a}$ & $0.034 \mathrm{ab}$ & $0.059 \mathrm{a}$ & $0.039 \mathrm{a}$ \\
\hline & $80 \%$ & $16.82 \mathrm{a}$ & $12.50 \mathrm{ab}$ & $13.4 \mathrm{a}$ & $14.8 \mathrm{a}$ & $0.164 \mathrm{ab}$ & $0.102 \mathrm{~b}$ & $0.042 \mathrm{ab}$ & $0.021 \mathrm{~b}$ & $0.034 \mathrm{a}$ & $0.027 \mathrm{a}$ \\
\hline \multirow{3}{*}{$90 \mathrm{DAE}$} & $0 \%$ & $10.00 \mathrm{~b}$ & - & $19.38 \mathrm{a}$ & - & $0.151 \mathrm{ab}$ & - & $0.058 \mathrm{a}$ & - & $0.091 \mathrm{a}$ & - \\
\hline & $50 \%$ & $11.50 \mathrm{~b}$ & $9.66 \mathrm{~b}$ & $17.22 \mathrm{a}$ & $14.70 \mathrm{a}$ & $0.186 \mathrm{a}$ & $0.065 \mathrm{~b}$ & $0.073 \mathrm{a}$ & $0.037 \mathrm{a}$ & $0.070 \mathrm{ab}$ & $0.024 \mathrm{~b}$ \\
\hline & $80 \%$ & $15.70 \mathrm{a}$ & $11.74 \mathrm{~b}$ & $14.00 \mathrm{a}$ & $14.70 \mathrm{a}$ & $0.136 \mathrm{ab}$ & $0.123 \mathrm{ab}$ & $0.039 \mathrm{a}$ & $0.062 \mathrm{a}$ & $0.032 \mathrm{ab}$ & $0.029 \mathrm{~b}$ \\
\hline
\end{tabular}

* Means followed by the same letters, in the columns, considering the same time and two irrigation regimes, are not significantly different by the Tukey test at $5 \%$.

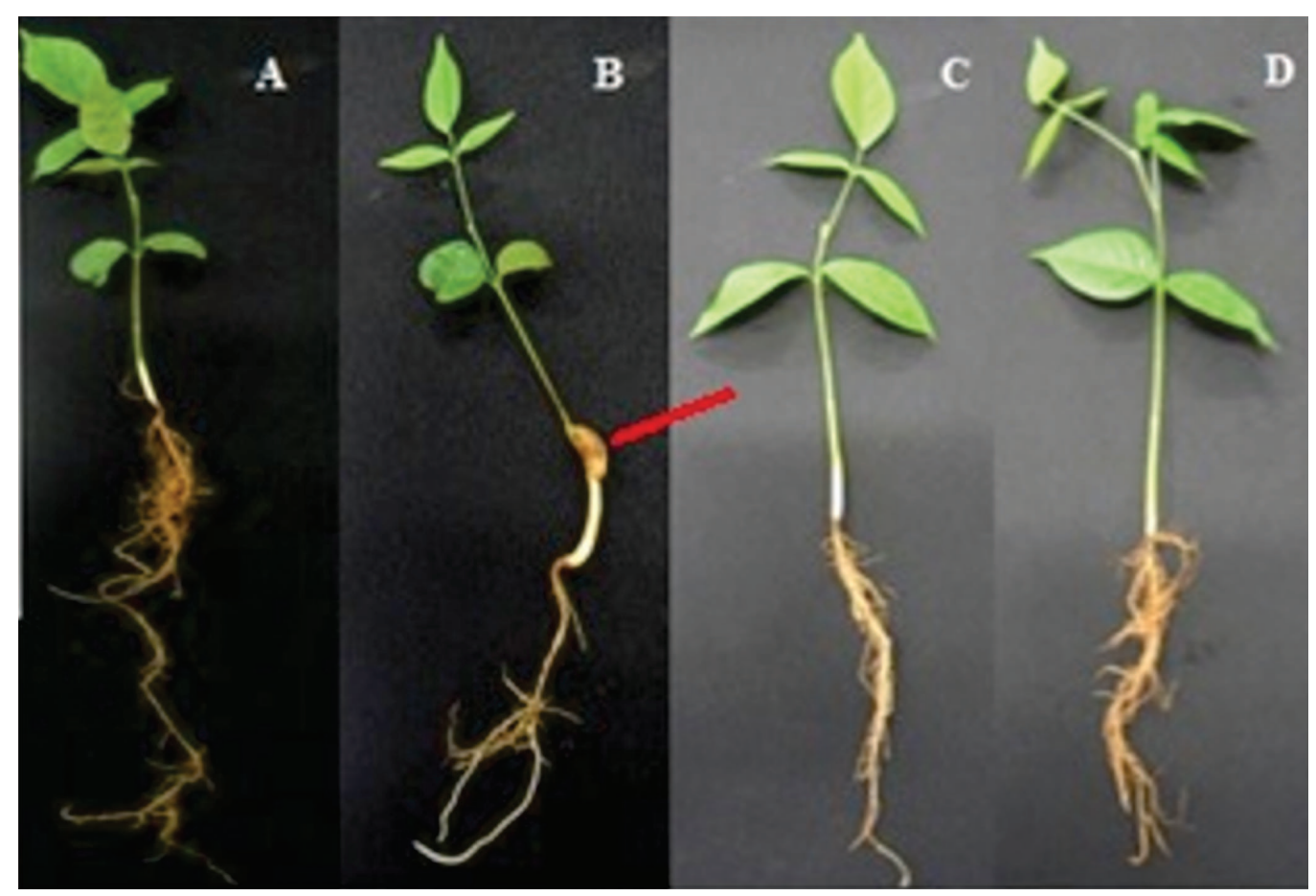

Figure 1: Lonchocarpus cultratus at 30 days after emergence (DAE), under $0 \%$ shade and daily irrigation (0\% ID), (B) $0 \%$ shade and non-daily irrigation (0\% NDI), (C) $50 \%$ shade mesh and daily irrigation (50\% ID), and (D) $80 \%$ shade mesh and daily irrigation (80\% ID). Arrow indicating persistence of cotyledon.

Rev. Ceres, Viçosa, v. 65, n.6, p. 491-499, nov/dez, 2018 
with reduction in dry root mass at 30 and 90 DAE and increased leaf area at 60 DAE. L. cultratus is a heliophite species and depending on the environment can behave as a pioneer, initial or late secondary (Almeida et al., 2016). The results of this study show the plasticity of the species, which changes morphological characteristics such as dry mass and leaf area, according to the light intensity.

\section{Chlorophyll content}

At 30 DAE, the chlorophyll $a$ content was significantly higher in the 0\% NDI treatments and the lowest values were observed for the treatments $0 \%$ ID, 50\% NDI and $80 \%$ ID (Figure 3). Chlorophyll $b$ content was higher in the treatments $0 \%$ NDI, $50 \%$ ID, and $80 \%$ NDI. The plants from the treatment $80 \%$ NDI had the highest total chlorophyll content, superior to those under 0\% ID, 50\% NDI, and $80 \%$ ID, while plants under $0 \%$ NDI and $50 \%$ ID were not different from the other treatments in relation to total chlorophyll content (Figure 3).

Comparison of chlorophyll $a$ and $b$ in the same treatment, at $30 \mathrm{DAE}$, showed that the content of chlorophyll $b$ was higher in plants under the treatments
$0 \%$ ID, 50\% ID, 50\% NDI, and 80\% ID, whereas plants under $0 \%$ NDI and $80 \%$ NDI were not significantly different for chlorophyll $a$ and $b$.

At 60 DAE, significant differences between the contents of chlorophyll $a$ and $b$ were found for the treatments $50 \%$ ID and $80 \%$ NDI, but comparing the treatments, in relation to the content of chlorophyll $a, b$ and total, no significant differences were found (Figure 4)

The plants kept under $80 \%$ shade had the highest content of chlorophyll $a$ at 90 DAE (Figure 5). In this period, highest content of total chlorophyll was also observed in the plants under $80 \%$ NDI, while the lowest content was found in the plants under 0\% ID. Rego \& Possamai (2006) pointed out that the increase in chlorophyll content in leaves increases the light absorption capacity of different wavelengths. Thus, plants that grow in shade conditions are known to optimize light absorption capacity, increasing pigment densities (Tang et al., 2015). However, the lower content of chlorophyll $b$ and total observed in plants under $0 \%$ ID may be related to the fact that chlorophyll molecules have a more

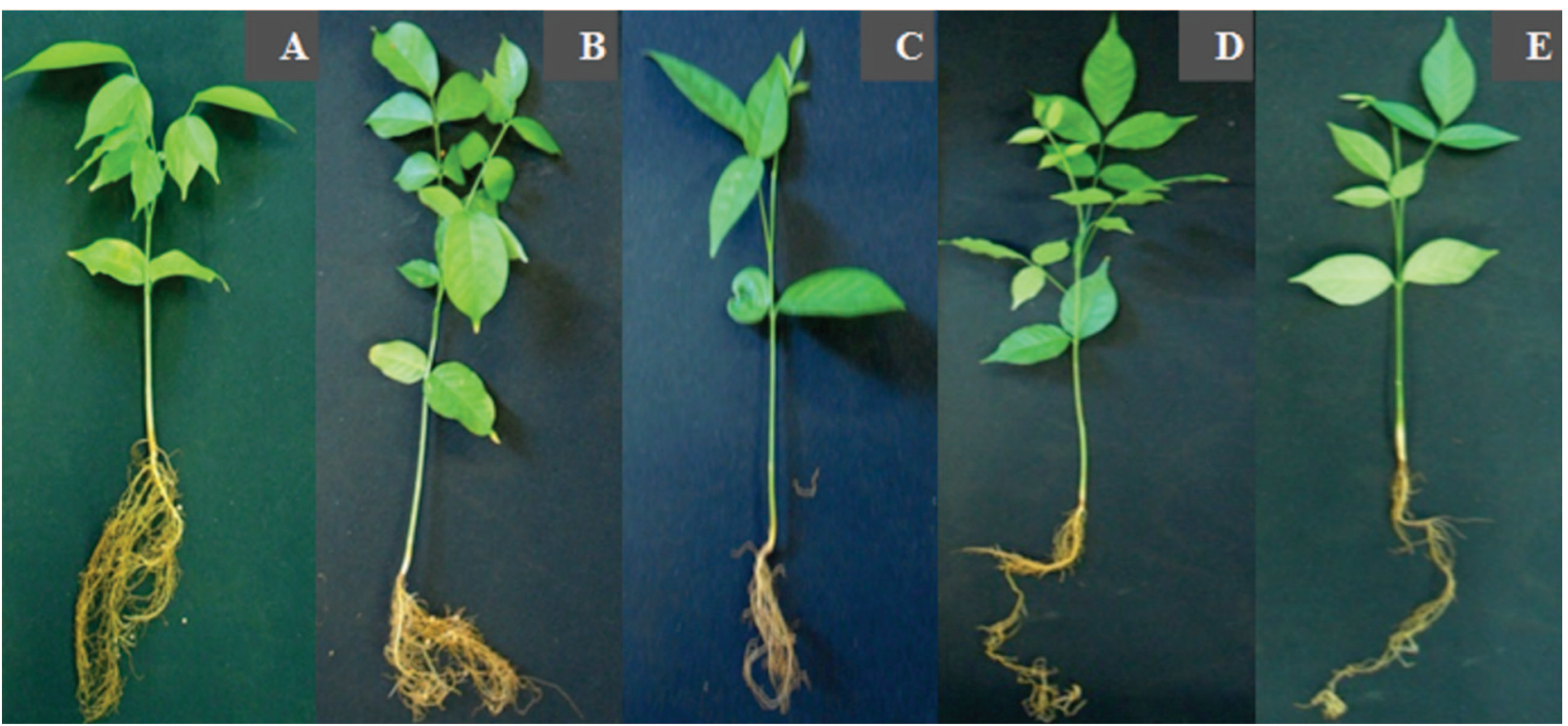

Figure 2: Lonchocarpus cultratus at 90 days after emergence (DAE) under 0\% shade and daily irrigation (0\% ID), (B) 50\% shade mesh and daily irrigation (50\% ID) or (C) non-daily irrigation (50\% NDI), (D) $80 \%$ shade mesh and daily irrigation (80\% ID) or (E) non-daily irrigation $(80 \% \mathrm{NDI})$.

Table 2: Leaf area $\left(\mathrm{cm}^{2}\right)$ of Lonchocarpus cultratus at 30, 60, and 90 days after emergence (DAE), kept in greenhouse under the treatments $0 \%$ shade, $50 \%$ shade; $80 \%$ shade; ID: daily irrigation; NDI: non-daily irrigation

\begin{tabular}{lccl}
\hline Treatment/DAT & $\mathbf{3 0}$ & $\mathbf{6 0}$ & $\mathbf{9 0}$ \\
\hline $0 \% \mathrm{ID}$ & $8.408 \mathrm{BC}^{*}$ & $6.764 \mathrm{~B}$ & $4.106 \mathrm{~B}$ \\
$50 \% \mathrm{ID}$ & $9.083 \mathrm{ABC}$ & $12.240 \mathrm{~A}$ & $6.924 \mathrm{AB}$ \\
$50 \% \mathrm{NDI}$ & $6.311 \mathrm{C}$ & $10.723 \mathrm{~A}$ & $4.989 \mathrm{AB}$ \\
$80 \% \mathrm{ID}$ & $11.595 \mathrm{~A}$ & $13.930 \mathrm{~A}$ & $7.798 \mathrm{~A}$ \\
$80 \% \mathrm{NDI}$ & $12.492 \mathrm{~A}$ & $12.910 \mathrm{~A}$ & $5.928 \mathrm{AB}$ \\
\hline
\end{tabular}

*Data followed by different letters in the columns are significantly different by the Tukey test at $5 \%$. 
pronounced degradation under intense radiation (Ferreira et al., 2012).

The higher content of chlorophyll $b$ is generally observed in shaded plants (Taiz \& Zeiger, 2009), which was confirmed for $L$. cultratus since the chlorophyll $b$ content was higher in shaded plants in comparison with plants maintained under 0\% ID (Figures 3 and 5). The increase in chlorophyll $b$ content in plants kept under low light intensity is an important mechanism of acclimation to shade, and is found in young plants of different native species kept under shading (Dutra et al., 2012; Nery et al., 2011; Scalon et al., 2003).

Young plants of Maclura tinctoria (L.) D.Don ex Steud. (Fustic Tree), Senna macranthera (DC. Ex Collad.) H.S. Irwin \& Barneby (Cassia), and Hymenaea courbaril L. (courbaril) increased total chlorophyll content when kept under shade (Almeida et al., 2005). The same was observed by Felsemburgh et al. (2016) for seedlings of Aniba parviflora (Meisn.) Mez and by Lenhard et al. (2013) for Caesalpinia ferrea Mart. Ex Tul.

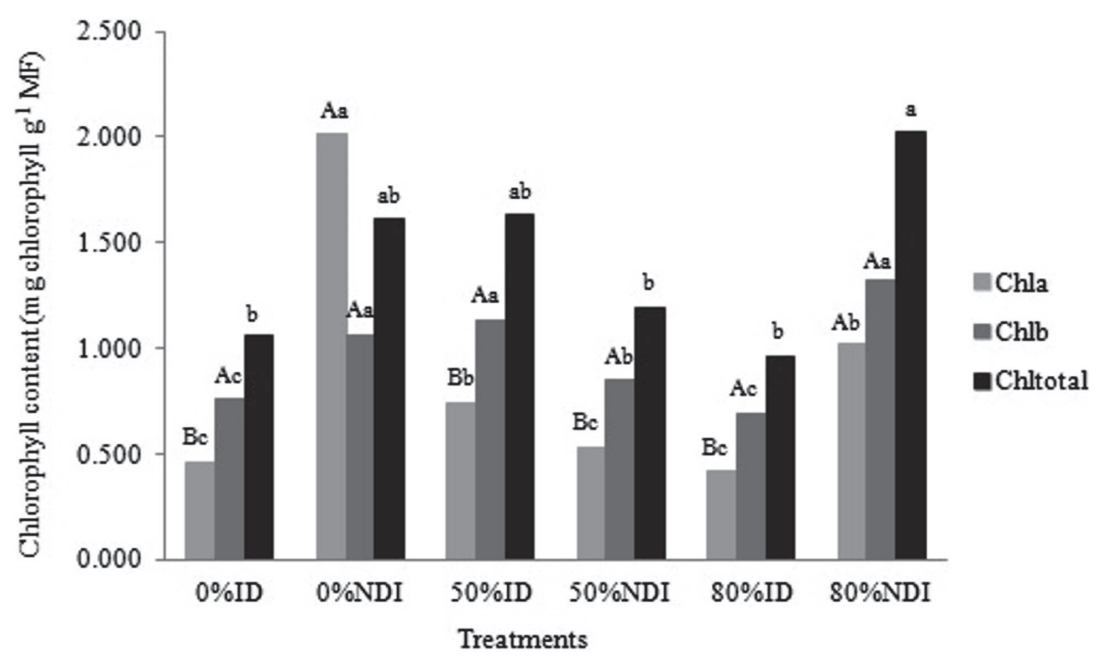

*Capital letters compare chlorophyll $a$ and $b$ in each treatment, alone; Small letters compare the content of chlorophyll $a, b$, and total among all treatments $(\mathrm{p}<0.05)$.

Figure 3: Content of chlorophyll $a, b$, and total of Lonchocarpus cultratus at 30 days after emergence (DAE) under $0 \%$ shade and daily irrigation (0\% ID), $0 \%$ shade and non-daily irrigation (0\% NDI), 50\% shade mesh and daily irrigation (50\% ID), $80 \%$ shade mesh and daily irrigation ( $80 \%$ ID), and $80 \%$ shade mesh and non-daily irrigation (80\% NDI).

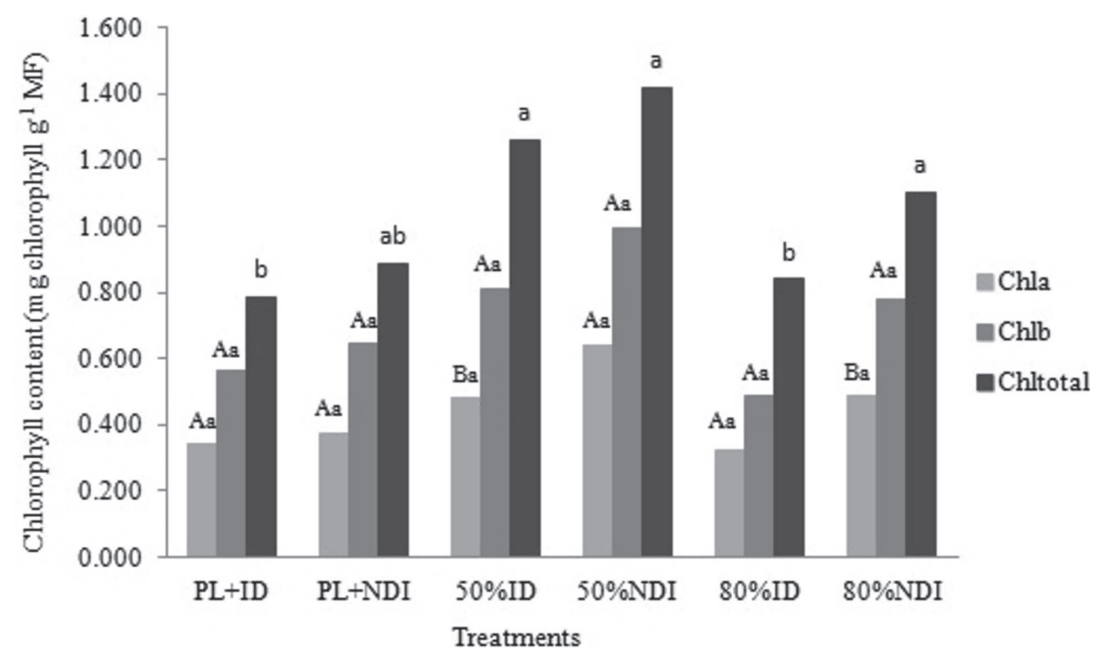

*Capital letters compare chlorophyll $a$ and $b$ in each treatment, alone; Small letters compare the content of chlorophyll $a$, $b$, and total among all treatments $(\mathrm{p}<0.05)$.

Figure 4: Content of chlorophyll $a, b$, and total of Lonchocarpus cultratus at 60 days after emergence (DAE) under $0 \%$ shade and daily irrigation ( $0 \%$ ID), $0 \%$ shade and non-daily irrigation ( $0 \%$ NDI ), $50 \%$ shade mesh and daily irrigation (50\% ID), $80 \%$ shade mesh and daily irrigation ( $80 \%$ ID), and $80 \%$ shade mesh and non-daily irrigation (80\% NDI).

Rev. Ceres, Viçosa, v. 65, n.6, p. 491-499, nov/dez, 2018 
Comparing the contents of chlorophyll $a$ and $b$, in the same treatment, at $90 \mathrm{DAE}$, we found that the plants under $50 \%$ NDI and $80 \%$ NDI had higher content of chlorophyll $b$ than chlorophyll $a$, while in plants of the other treatments we found no significant differences between the contents of chlorophyll $a$ and $b$.

\section{Arbuscular mycorrhizal colonization and root nodulation}

Roots of L. cultratus of all treatments were colonized by arbuscular mycorrhizal fungi, and hyphae and vesicles were identified (Figure 6).

The percentages of arbuscular mycorrhizal colonization (AMC) in the roots of plants under $0 \%$ ID, 50\% ID, and $80 \%$ ID increased over the evaluation period and peaked at $90 \mathrm{DAE}$ (Figure 7).

Mycorrhizal plants are more resistant to water stress due to drought, as they are favored by the water-plant relationship promoted by the mycorrhizal fungus. The increase in the soil exploration capacity and consequently the nutritional status of the plants is not only caused by the hyphae functioning, but also by the increase in the root length at the depth at which mycorrhizal roots and fungi occupy the soil (Moreira \& Siqueira, 2002). AMC of plants under $0 \%$ NDI was lower than plants under $0 \%$ ID at 30 and 60 DAE (Figure 7), probably because the treatment with lower water availability was applied when the plants formed the first set of true leaves, i.e., at the

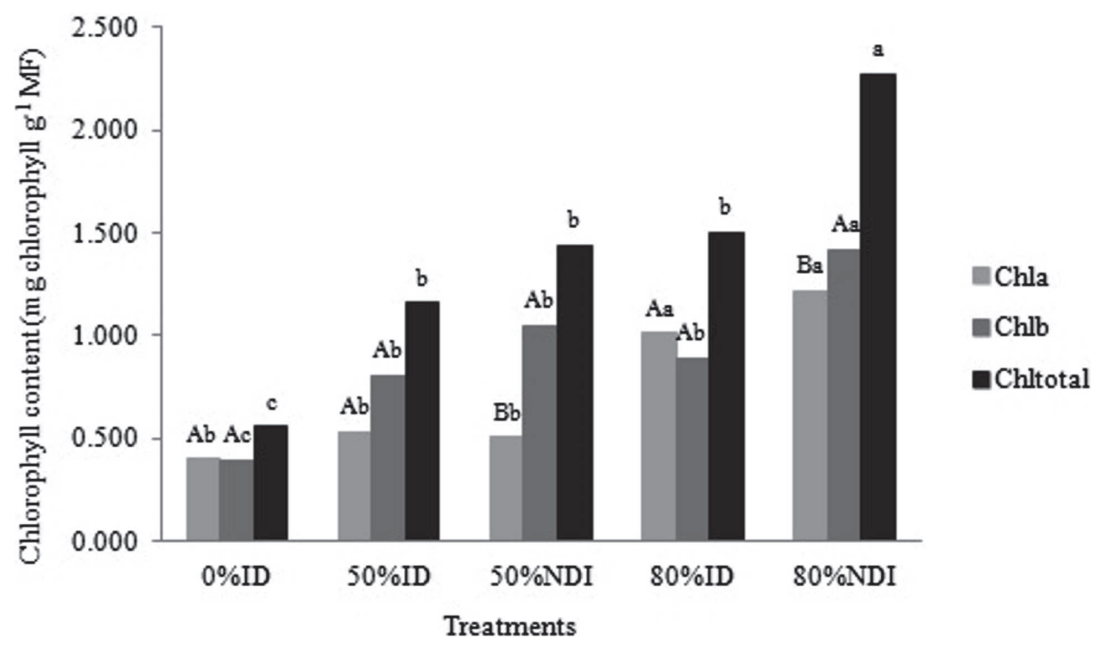

*Capital letters compare chlorophyll $a$ and $b$ in each treatment, alone; Small letters compare the content of chlorophyll $a$, $b$, and total among all treatments $(\mathrm{p}<0.05)$.

Figure 5: Content of chlorophyll $a, b$, and total of Lonchocarpus cultratus at 90 days after emergence (DAE) under $0 \%$ shade and daily irrigation (0\% ID), 50\% shade mesh and daily irrigation (50\% ID), $80 \%$ shade mesh and daily irrigation ( $80 \%$ ID), and $80 \%$ shade mesh and non-daily irrigation (80\% NDI).

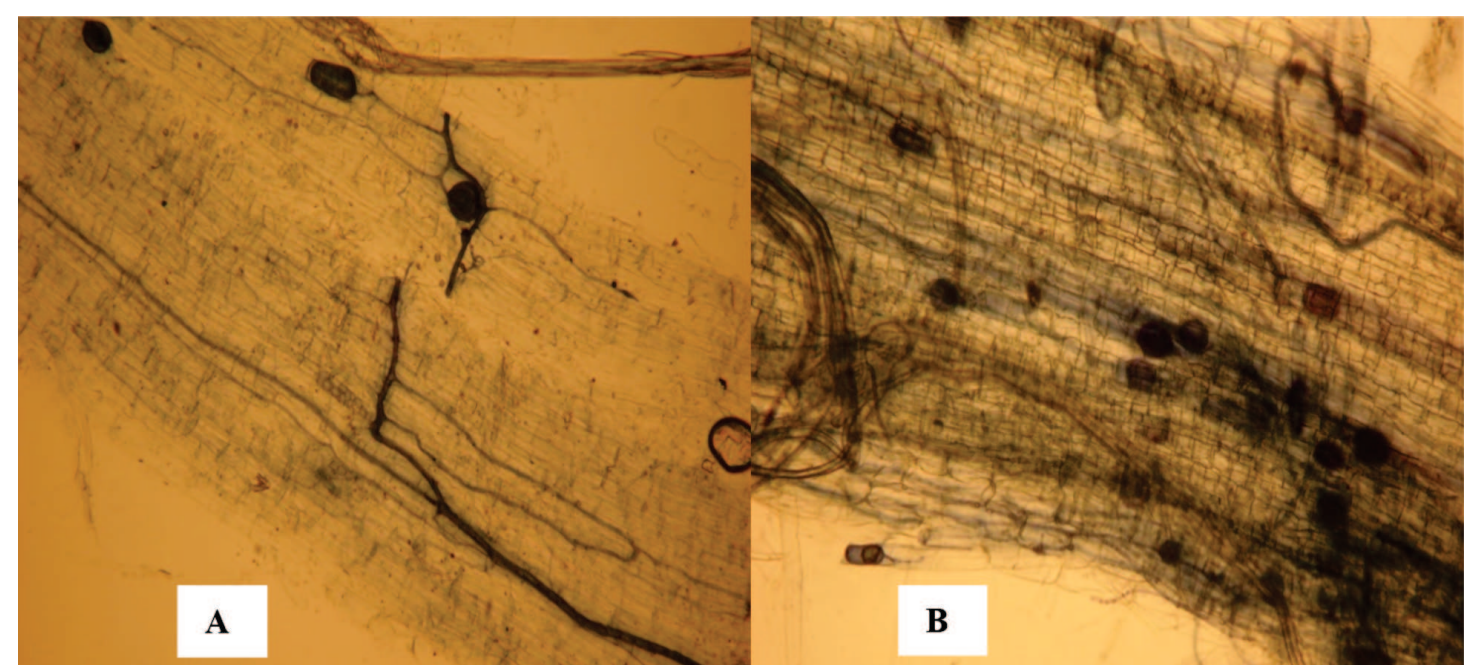

Figure 6: Root cortex of Lonchocarpus cultratus, A and B showing hyphae and vesicles of arbuscular mycorrhizal colonization. 


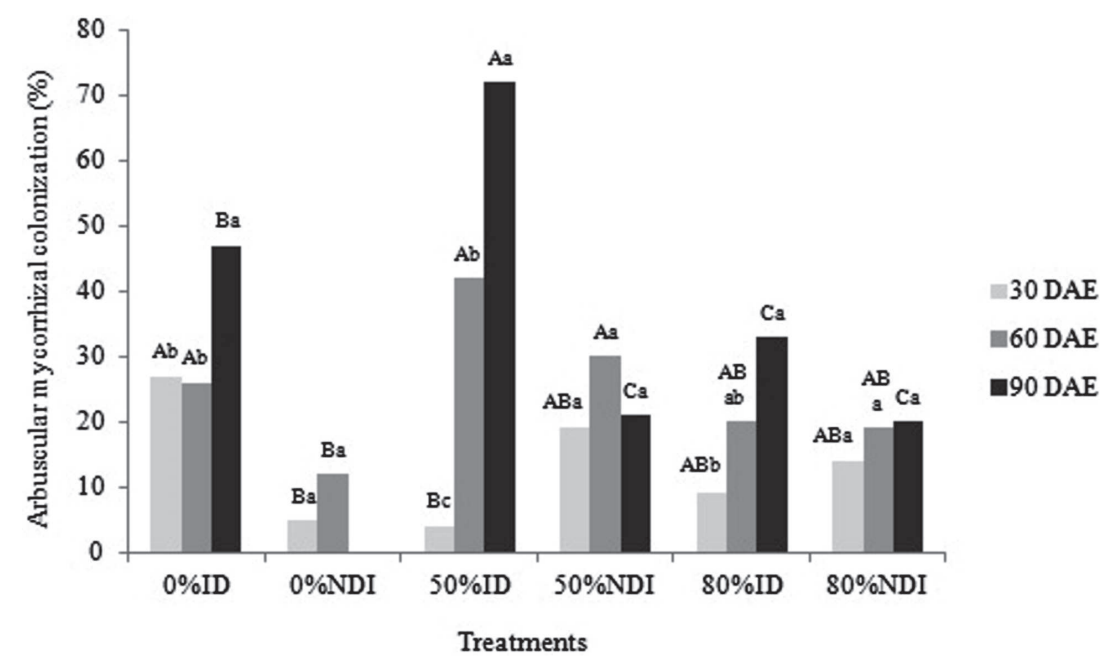

* Capital letters compare treatments on the same date;

Small letters compare the same treatment between dates $(\mathrm{p}<0.05)$.

Figure 7: Percentage of arbuscular mycorrhizal colonization in roots of Lonchocarpus cultratus under the different treatments.

beginning of the growth, making it difficult to establish the mycorrhizal association. This could also have determined the non-survival of the plants under 0\% NDI as early as 30 DAE, and death of all plants at 90 DAE. In addition, considering that carbohydrate allocation to the mycorrhizal association is strongly dependent on resource availability (Smith \& Read, 2008), the reduction of plant growth in the treatment $0 \%$ NDI and the consequent decrease in the synthesis of photoassimilates may have restricted the growth of arbuscular mycorrhizal fungi (AMF). The same association can be made for the plants kept under $80 \%$ shade, with low AMC percentage compared with the plants from treatments $0 \%$ ID and $50 \%$ ID, at 90 DAE (Figure 6). The plants under $80 \%$ shade allocated less carbon to the roots, which was demonstrated by the lower dry root biomass (Table 1) and may have contributed to reduction in mycorrhizal colonization.

Plants cultivated under 0\% ID had a higher production of root biomass (Table 1) and higher plant survival when compared with treatment $0 \%$ NDI, which can be attributed to mycorrhization of plants from $30 \mathrm{DAE}$ and increase at 90 DAE, allowing greater plant survival and development.

At $30 \mathrm{DAE}$, the formation of root nodules was limited, occurring in two plants maintained under $0 \%$ ID and in only one plant from the treatments $0 \%$ NDI and 50\% ID. At 60 DAE, all plants kept under 0\% ID presented nodules, differently from that observed with the treatment $50 \%$ ID, in which only one plant presented nodules. At the end of the experiment, at $90 \mathrm{DAE}$, all plants in all treatments presented nodules. The nodulation occurred spontaneously, and no inoculation procedure was performed. Pastorini et al. (2016) reported that Machaerium brasiliense Vogel presented nodules only after 180 days. The authors also mentioned that root nodulation is a characteristic of Fabaceae, and that information about nodulation capacity of most native trees is still lacking.

Environmental factors that affect the development of plants may change the formation and growth of nodules. The decrease in water potential can affect root growth and delay the formation of nodules (Ramos et al., 2003). It is likely that the delay in the formation of nodules in shaded plants is caused by the preferential allocation of resources to the growth of shoots, restricting, in that initial period of growth, the symbiotic association with the bacteria.

The nodules present in the roots of $L$. cultratus were rounded protrusions occurring in lateral roots, which was also observed by Pastorini et al (2016) in young plants of M. brasiliense and Oliveira (2001) in young plants of different species of Fabaceae.

\section{CONCLUSION}

Plants kept under shade presented lower dry root biomass at $30 \mathrm{DAE}$, and etiolated plants appeared under $80 \%$ ID at 90 DAE.

Plants under shading presented higher total chlorophyll content in comparison with the treatment $0 \%$ shade.

Daily irrigation and increased light availability led to higher arbuscular mycorrhizal colonization in young plants of L. cultratus, which also formed nodules in all treatments at 90 days of development.

Young L. cultratus plants maintained under $0 \%$ shade and low water availability did not survive until 90 DAE. 


\section{REFERENCES}

Almeida SMZ, Soares AM, Castro EM, Vieira CV \& Gajego EB (2005) Alterações morfológicas e alocação de biomassa em plantas jovens de espécies florestais sob diferentes condições de sombreamento. Ciência Rural, 35:62-68.

Almeida CG, Slusarski SR \& Souza MC (2016) The population structure of Lonchocarpus cultratus in an Atlantic Forest riparian zone of the upper Paraná River, Brazil. Acta Scientiarum. Biological Sciences, 38:411-417.

Amissah L, Mohren GMJ, Kyereh B \& Poorter L (2015) The effects of drought and shade on the performance, morphology and physiology of Ghanaian tree species. Plos One, 10:01-22.

Amo-Rodrigues S \& Gomez-Pompa A (1979) Clave para plántulas y estados juveniles de espécies primárias de una selva alta perinnifolia en Veracruz, México. Biotropica, 4:58-108.

Arnon DI (1949) Copper enzymes in isolated chloroplast polyphenoloxidase in Beta vulgaris. Plant Physiology, 24:0115 .

Beltrano J \& Ronco MG (2008) Improved tolerance of wheat plants (Triticum aestivum L.) to drought stress and rewatering by the arbuscular mycorrhizal fungus Glomus claroideum: Effect on growth and cell membrane stability. Brazilian Journal of Plant Physiology, 20:29-37.

Brzostek ER, Gragoni D, Schmid HP, Rahman AF, Smis D, Wayson CA, Johnson DJ \& Phillips RP (2014) Chronic water stress reduces tree growth and the carbon sink of deciduous hardwood forests. Global Change Biology, 20:2531-2539.

Caron BO, Souza VQ, Cantarelli EB, Manfron PA, Behling A \& Eloy E (2010) Crescimento em viveiro de mudas de Schizolobium parahyba (Vell.) S.F.Blake, submetidas a níveis de sombreamento. Ciência Florestal, 20:663-689.

Dutra TR, Massad MD \& Santana RC (2012) Parâmetros fisiológicos de mudas de copaíba sob diferentes substratos e condições de sombreamento. Ciência Rural, 42:1212-1218.

Ferri CP (2004) Narrow band spectral indexes for chlorophyll determination in soybean canopies. Brazilian Journal of Plant Physiology, 16:131-136.

Ferreira WN, Zandavalli RB, Bezerra AME \& Medereiros filho S (2012) Crescimento inicial de Piptadenia stipulacea (Benth.) Ducke (Mimosaceae) e Anadenanthera colubrina (Vell.) Brenan var. cebil (Griseb.) Altshul (Mimosaceae) sob diferentes níveis de sombreamento. Acta Botanica Brasilica, 26:408-414.

Felsemburgh CA, Santos KJS, Camargo PB, Carmo JB \& Tribuzy ES (2016) Respostas ecofisiológicas de Aniba parviflora ao sombreamento artificial. Pesquisa Florestal Brasileira, 36:201210 .

Giovannetti M \& Mosse B (1980) An evaluation of techniques for measuring vesicular-arbuscular mycorrhizal infection in roots. New Phytologist, 84:489-500.

Gonçalves JFC, Silva CEM \& Guimarães DG (2009) Fotossíntese e potencial hídrico foliar de plantas jovens de andiroba submetidas à deficiência hídrica e à reidratação. Pesquisa Agropecuária Brasileira, 44:08-14

Lenhard NR, Paiva Neto VB, Scalon SPQ \& Alvarenga AV (2013) Crescimento de mudas de pau-ferro sob diferentes níveis de sombreamento. Pesquisa Agropecuária Tropical, 43:178-186.

Li T, Huang L-X, Yi L, Hong L, Shen H, Ye W-H \& Wang Z-M (2016) Comparative analysis of growth and physiological traits between the natual hybrid Sphagneticola trilobata $\mathrm{x}$ calendulacea and its parental species. Nordic Journal of Botany, 34:219-227.
Mendes HSJ, De Paula NF, Scarpinatti EA \& De Paula RC (2013) Respostas fisiológicas de genótipos de Eucalyptus grandis x E. urophylla à disponibilidade hídrica e adubação potássica. Cerne, 19:603-611.

Moreira FMS \& Siqueira JO (2006) Microbiologia e bioquímica do solo. $2^{\mathrm{a}}$ ed. Lavras, Editora da UFLA. 729p.

Nery FC, Oliveira HM, Alvarenga AA, Sara Dousseau S, Castro EM \& Campos AAAL (2011) Initial development and gas exchange of Talisia subalbens (Mart.) Radlk. under different shading conditions. Revista Árvore, 35:61-67.

Oliveira DMT (2001) Morfologia comparada de plântulas e plantas jovens de leguminosas arbóreas nativas: espécies de Phaseoleae, Sophoreae, Swartzieae e Tephrosieae. Revista Brasileira de Botânica, 24:85-97.

Panarari RS, Prioli AJ, Prioli MAP, Souza MC, Oliveira AV, Boni TA, Lucio LC \& Prioli LM (2004) Molecular polymorphism in Lonchocarpus cultratus (Fabaceae) from riparian areas of natural reforesting in Upper Paraná River, Brazil. Acta Scientiarum. Biological Sciences, 26:335-341.

Pastorini LH, Romagnolo MB, Barbeiro C, Guerreiro RGO, Costa PM, Sert MA \& Souza LA (2016) Germinação e crescimento de Machaerium brasiliense Vogel (Fabaceae) em casa de vegetação. Floresta, 46:83-92.

Phillips JM \& Hayman DS (1970) Improved procedures for clearing roots and staining parasitic and vesicular-arbuscular mycorrhizal fungi. New Phytologist, 124:481-488.

Ramos MLG, Parsons R, Sprent JI \& James EK (2003) Effect of water stress on nitrogen fixation and nodule structure of common bean. Pesquisa Agropecuária Brasileira, 38:339-347.

Rawat JM, Rawat B, Tewari A, Joshi S, Nandi SK, Palni LM \& Prakash A (2017) Alterations in growth phtosynthetic activity and tissue-water relations of tea clones in response to different soil moisture content. Trees, 31:941-952.

Rego GM \& Possamai E (2006) Efeito do sombreamento sobre o teor de clorofila e crescimento inicial do Jequitibá-rosa. Boletim de Pesquisa Florestal, 53:179-194.

Scalon SPQ, Mussury RM, Rigoni MR \& Scalon Filho H (2003) Crescimento inicial de mudas de Bombacopsis glabra (Pasq.) A. Robyns sob condições de sombreamento. Revista Árvore, 27:753-758.

Silva BMS, Lima JD, Danta VAV, Moraes WS \& Sabonaro DZ (2007) Efeito da luz no crescimento de mudas de Hymenaea parvifolia Huber. Revista Árvore, 30:166-169.

Silva MJ \& Tozzi AMGA (2012) Revisão taxonômica de Lonchocarpus s. str. (Leguminosae, Papilionoideae) do Brasil. Acta Botanica Brasilica, 26:357-377.

Souza LA \& Oliveira JHG (2004) Morfologia e anatomia das plântulas de Tabebuia avellanedae Lor. ex Griseb e T. chrysotricha (Mart. ex Dc.) Standl. (Bignoniaceae). Acta Scientiarum. Biological Sciences, 26:217-226.

Smith SE \& Read DJ (2008) Mycorrhizal symbiosis. $3^{\text {rd }}$ Edition. New York, Academic Press. 787p.

Taiz L \& Zeiger E (2009) Fisiologia Vegetal. $4^{\mathrm{a}}$ ed. Porto Alegre, Artmed. 819p.

Tang H, Hu YY, Yu W-W, Song LL \& Wu J-S (2015) Growth, photosynthetic and physiological responses of Torreya grandis seedlings to varied light environments. Trees, 29:10111022. 